Abstracta Iranica Abstranica

Revue bibliographique pour le domaine irano-aryen

Volume 28 | 2007

Comptes rendus des publications de 2005

\title{
" Archaeological Research at Suhâr 1980-1986 ». Journal of Oman Studies 13, 2004, pp. 263-381.
}

\section{Audrey Peli}

\section{(2) OpenEdition}

1 Journals

\section{Édition électronique}

URL : http://journals.openedition.org/abstractairanica/11522

DOI : 10.4000/abstractairanica. 11522

ISSN : 1961-960X

Éditeur :

CNRS (UMR 7528 Mondes iraniens et indiens), Éditions de l'IFRI

\section{Édition imprimée}

Date de publication : 15 mai 2007

ISSN : 0240-8910

\section{Référence électronique}

Audrey Peli, « « Archaeological Research at Suhâr 1980-1986 ». Journal of Oman Studies 13, 2004, pp. 263-381. », Abstracta Iranica [En ligne], Volume 28 | 2007, document 228, mis en ligne le 18 septembre 2007, consulté le 25 septembre 2020. URL : http://journals.openedition.org/ abstractairanica/11522 ; DOI : https://doi.org/10.4000/abstractairanica.11522

Ce document a été généré automatiquement le 25 septembre 2020.

Tous droits réservés 


\title{
« Archaeological Research at Suhâr 1980-1986 ». Journal of Oman Studies 13, 2004, pp. 263-381.
}

\author{
Audrey Peli
}

1 L'article relate la fouille française faite entre 1980 et 1986 sur ce qui fut la grande ville portuaire du 'Umân du haut moyen âge et jusqu' aux alentours du XII ${ }^{\mathrm{e}-X I I I}$ s. de l'è.c. (après des sondages limités, inaboutis ou inédits tentés entre 1958 et 1975 par d'autres équipes). Le principal sondage ouvert au centre de la vieille ville, au point le plus haut du tell, révéla $7 \mathrm{~m}$ de dépôts archéologiques. Les premiers niveaux d'occupation pourraient être un peu antérieure aux Sassanides (milieu ou fin du $\mathrm{II}^{\mathrm{e}} \mathrm{s}$.). Suhâr apparaît dès l'origine comme une ville (ou comptoir) créé pour le commerce, avec l'Inde d'abord, et plus tard, avec la Chine, peut-être dès la fin de l'époque sassanide. La ville comme sa région, sous une forte influence de la Perse, sont alors connues sous le nom de Mâzûn. En l'absence de monnaies ou de tout élément de datation absolue, l'identification du passage aux premiers siècles de l'hégire n'est pas facile à préciser et ce n'est qu'avec les premières glaçures blanches opaques et les premiers types de porcelaine bien connus qu'on entre avec certitude dans la période abbasside. Vers le $\mathrm{IX}^{\mathrm{e}}-\mathrm{X}^{\mathrm{e}}$ s. la ville sort de ses limites anciennes, le vieux centre est abandonné au petit artisanat et de grandes habitations s'étendent vers le nord et le sud. Elles ont livré un abondant matériel céramique importé de la Chine et de l'Inde. A cette époque la communauté des marchands juifs de Sohar devait être nombreuse et une douzaine de leurs tombes existent toujours dans un cimetière, en limite de la ville médiévale.

2 Un prochain article du JOS sera consacré à la période postérieure au XII ${ }^{\mathrm{e}} \mathrm{s}$. Elle correspond à l'émergence du pouvoir de Qish, puis de celui de la principauté d'Ormuz, enfin à la présence des Portugais. Après ces événements, Sohar avait définitivement perdu son rôle prépondérant au profit de Qalhât, Zafar/Dhofar et Mascate. 
INDEX

Thèmes : 5.1. Monde iranophone

\section{AUTEURS}

AUDREY PELI

Paris 